\title{
Vicia faba: a cheap and sustainable source of protein and its application in beef products
}

\author{
N. Sulaiman ${ }^{1,2,3}$, C. Orfila ${ }^{2}$, P. Ho ${ }^{3}$ and J. Maycock ${ }^{1}$ \\ ${ }^{1}$ Food Chemistry and Biochemistry, ${ }^{2}$ Nutrition and Public Health and ${ }^{3}$ Food Colloids and Processing, School of Food \\ Science and Nutrition, Faculty of Mathematics and Physical Sciences, University of Leeds, LS2 9JT, UK.
}

Health and environmental concerns associated with meat consumption has led to an increase in the demand for alternative sources of protein. Blending beef with non-animal proteins $(30 \% \mathrm{w} / \mathrm{w})$ could reduce calorific intake and reduce greenhouse gas emissions significantly ${ }^{(1,2)}$. Vicia faba is a legume species widely grown across the world and it is rich in protein and fibre, though its application to human nutrition has been limited due to presence of anti-nutrients such as vicine and convicine $e^{(2,3)}$.

The aim of this study is to optimise the preparation of Vicia faba protein isolate (VFPI) and characterise its nutritional and functional properties when combined with beef mince to make patties. Protein was extracted from ground bean using in $0 \cdot 25 \%(\mathrm{w} / \mathrm{v}$ ) sodium sulphite at $\mathrm{pH} 7.6$ for 1 hour at room temperature. The protein and fibre content of the recovered isolate were compared to commercial legume extracts (Table 1). VFPI showed lower protein content and higher fibre content compared to commercial legumes. Proteins in VFPI were characterised by SDS-PAGE and LC-MS of digested proteins. Peptide alignment against Uniprot databases identified the most abundant proteins as legumins (LEB4 and 7), vicilin and favin. Analytical LC-MS analysis showed significantly lower levels $(\mathrm{p}<0.05)$ of vicine $(0.2 \%)$ and convicine $(0.13 \%)$ in VFPI, compared to the original raw material $(0.7 \%$ vicine and $0.3 \%$ convicine).

Table 1. Total protein and dietary fibre content of VFPI (values show mean of 3 independent extractions), commercial soya and pea protein isolates (PI). *values from the product label, ND = not determined.

\begin{tabular}{lcccc}
\hline Samples & Protein $(\%)$ & SD & Fibre $(\%)$ & SD \\
\hline VFPI & $42 \cdot 7$ & $1 \cdot 0$ & $17 \cdot 6$ & $3 \cdot 8$ \\
Soya PI & $70 \cdot 5$ & $7 \cdot 3$ & $1 \cdot 0^{*}$ & ND \\
Pea PI & $69 \cdot 2$ & $4 \cdot 7$ & $2 \cdot 5^{*}$ & ND \\
Beef & $19 \cdot 7^{*}$ & ND & $0 \cdot 0^{*}$ & ND \\
\hline
\end{tabular}

Table 2. Calculated protein and fibre content of beef patties and experimental product yield (values show mean of 3 independent preparations). The values with different letter superscripts are significantly different $(\mathrm{p}<0.05)$.

\begin{tabular}{lccc}
\hline Samples & Protein $(\%)$ & Fibre $(\%)$ & Product yield (\%) \\
\hline Beef patty & $19 \cdot 7$ & $0 \cdot 0$ & $82 \cdot 3^{\mathrm{a}}$ \\
Beef + VFPI patty & $24 \cdot 3$ & $3 \cdot 5$ & $91 \cdot 0^{\mathrm{b}}$ \\
Beef + Soya PI patty & 29.9 & $0 \cdot 2$ & $91 \cdot 1^{\mathrm{b}}$ \\
Beef + Pea PI patty & $29 \cdot 6$ & $0 \cdot 5$ & $90 \cdot 9^{\mathrm{b}}$ \\
\hline
\end{tabular}

Addition of $20 \%$ (w/w) VFPI to beef mince $(15 \%$ fat) improved product yield significantly $(\mathrm{p}<0 \cdot 05)$ and higher fibre content compared to beef patties made with $100 \%$ beef (Table 2). The cost of the patty reduced by $17 \%$ and the carbon footprint could theoretically reduce by $16 \%$ from $26.6 \mathrm{~kg} \mathrm{CO}_{2} / \mathrm{kg}$ to $22.3 \mathrm{~kg} \mathrm{CO}_{2} / \mathrm{kg}_{\text {of produce }}{ }^{(4)}$. Future work will focus on the sensory evaluation and consumer acceptance of beef patties enriched with plant proteins using human volunteers.

In conclusion, Vicia faba could be used as an alternative source of protein to replace $20 \%$ of meat with potential positive implications for health and the environment.

1. Editorial (2018) Nature 555, 560.

2. Asgar MA, Fazilah A, Huda N et al. (2010) Compr Rev Food Sci Food Saf 9(5), 513-29.

3. Boye J, Zare F \& Pletch A (2010) Food Res Int 43(2), 414-31.

4. Clune S, Crossin E \& Verghese K (2017) J Clean Prod 140, 766-83. 